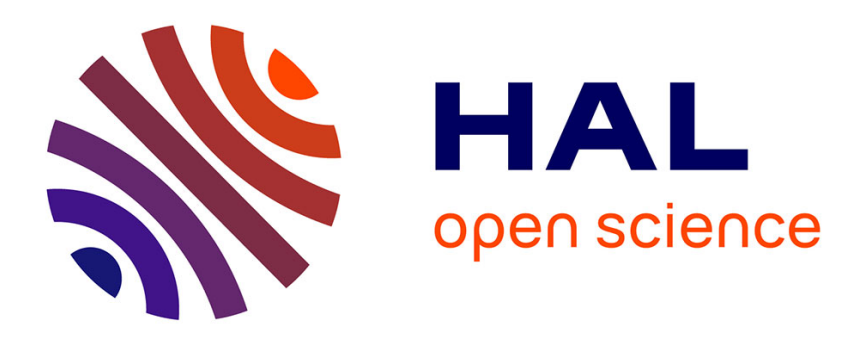

\title{
Topicalization in Berber: a typological perspective
}

Mena B. Lafkioui

\section{To cite this version:}

Mena B. Lafkioui. Topicalization in Berber: a typological perspective. STUF, 2014, 67 (1), pp.97-112. hal-01111657

\section{HAL Id: hal-01111657 \\ https://hal.science/hal-01111657}

Submitted on 30 Jan 2015

HAL is a multi-disciplinary open access archive for the deposit and dissemination of scientific research documents, whether they are published or not. The documents may come from teaching and research institutions in France or abroad, or from public or private research centers.
L'archive ouverte pluridisciplinaire HAL, est destinée au dépôt et à la diffusion de documents scientifiques de niveau recherche, publiés ou non, émanant des établissements d'enseignement et de recherche français ou étrangers, des laboratoires publics ou privés. 
Mena Lafkioui

\section{Topicalization in Berber: a typological perspective}

Abstract: This article addresses the phenomenon of topicalization from a typological perspective, both at the level of the Berber phylum and at the crosslinguistic level. It aims at providing Berber's principal linguistic properties and mechanisms of topicalization in comparison with cross-linguistic accounts so as to better understand the connection between syntax and information structure, which in Berber is subject to variation and to a complex interplay with prosody.

Keywords: topicalization, information structure, typology, constituent order

Mena Lafkioui: Department of Languages and Cultures, Ghent University, 9000 Gent, Belgium. E-mail: Mena.Lafkioui@ugent.be

\section{Introduction ${ }^{1}$}

In this study, topicalization is considered from an interactional viewpoint (Lafkioui 2010, 2011a) and thus as a discursive process that is employed to attract the attention of interactants towards a specific discourse object (viz. topic). Once the proposed or negotiated topic is accepted, various discursive operations intervene in order to maintain, delineate, develop or to call to mind the interactional perspective that the interactants have mutually chosen, so as to establish a certain discursive continuity (viz. thematic continuity) until they decide otherwise. Each new topicalization thus implies a re-centering of the interactants' attention, which goes hand in hand with a partial or total rupture with the preceding topicalization. So, the choice of the topic depends not only on the linguistic context in which it occurs - related to topicality parameters such as the degree of animacy of the noun phrase referent, its semantic role and its degree of specification (Croft 1990: 112-113; Siewierska 1984: 221) - but also on its extralinguistic context; that is, the interaction situation, comprising all social and cultural knowledge and practices shared by the interactants at that precise interactional instance.

1 Abbreviations used in this article are listed at the end of this article. Topics and co-referents are indicated in bold. Quoted data are represented according to the authors' transcription system. The English translations are mostly mine. 
However, there is a certain tendency to structure content around semantic referents that can be identified within a relatively accessible linguistic context. Specification (determination) is an important linguistic parameter for the selection of topics, especially when they are noun phrases (NP). Because of their inherently highly topical nature, which is the result of their elevated position on the animacy and semantic hierarchies, arguments that relate to human agents are often chosen to function as topics. That is why there is a general cross-linguistic inclination to match the discursive NP topic with the corresponding subjectargument; both often occupy the same distributional position (Givón 1979: 58, 64). This kind of default topic (also called weak topic) is distinct from what I shall call the "marked topic", which is the product of a topicalization process in which specific marking procedures (e.g. left dislocation, intonation, particular morphemes) are employed so as to create contrast or emphasis. It is this latter type of topic and topicalization phenomena that I will deal with in this article.

Following this introduction, a general comparative analysis of the marked topic in Berber is given in section 2, with special focus on its various defining parameters, its co-referring system and its compatibility with other topics in one and the same utterance. Section 3 investigates the phenomenon of topicalization cross-linguistically, some conclusions on which are presented at the end of this article.

\section{The Berber marked topic}

On the grammatical level, three main parameters determine the NP topic ${ }^{2}$ in Berber: the morphosyntactic parameter (free noun state), the syntagmatic parameter (chiefly, left dislocation) and the prosodic parameter (intonation dislocation). Consider, for example, the following topics in bold:

(1) Taqbaylit, North Algeria

azru, $y$-T'awi t iD nT'a

'The stones, he brought (them) himself.'

[Chaker 1983: 455]

(2) Tashelhit, South Morocco

tamgart-ann(,) dar-s asərdun.

'This woman, she has a mule.'

[Lafkioui 1999: chapter 2.1.1]

2 Also commonly called "indicateur de thème" in Berber linguistics, a term coined by Galand (1964). 
Both topics are marked by their free state: azru (FS) instead of uzru (DS) for (1) and tamgart-ann (FS) instead of tomgart-ann (DS) for (2). They occupy a pre-predicative (sentence-initial) position; a pre-verbal one (example 1) and a pre-nominal one (example 2) respectively. Moreover, they are separated from the corresponding predicative syntagms by an intonation rupture, indicated by (,) in my own examples. ${ }^{3}$

\subsection{The morphosyntactic parameter}

Although the FS is an important feature of the NP topic in Berber, it is not operative and hence not decisive in every case. In fact, a large number of nouns do not morphologically indicate the noun state opposition, mostly because of their intrinsically determined nature, such as proper nouns (3), kinship terms (4) and pronouns (5), but also those nouns with a unique state (6):

(3) Jerbi, South Tunisia

Rebbi ed ennbi, g lektub, am-yuh emlen. ${ }^{4}$

'God and the Prophet, in the Book, (it is just) like this they said.'

[Brugnatelli unpublished text]

(4) Tarifit, North Morocco

baba-s(,) yāwwậ-d asaggwas- $a$.

'His father, he came back home this year.'

(5) Tamasheq, Burkina Faso

năkku, ad ăkkăg Gorăn.

'Myself, I will go to Gorom.'

[Sudlow 2001: 75]

(6) Tamazight, Central Morocco

lqhwa-y-u uliD am tDin tSm i lqšla

'This coffee, it is not like the kind you drink in the barracks.'

[Bentolila 1981: 246]

3 Unfortunately, many scholars do not indicate prosodic markers in their transcriptions, which excludes a lot of data from a proper analysis of this phenomenon.

4 Note here the combination of a double topic and the cleft focus structure am-yuh emlen. 


\subsection{The syntagmatic parameter}

The Berber topic usually takes a pre-predicative position in the syntagmatic configuration. This slot is even its default position in relatively simple constructions, as is shown in examples (1) to (6). This preference for left dislocation has probably to do with the fact that this position makes it especially easy to spot the topic (discursive referent) to which the asserted message can be attached and, consequently, predication can be completed. Yet this privileged position is just a subsidiary characteristic of topicalization, since natural spoken data - where complex constructions are often the norm - repeatedly prove that the topic in Berber may also occur in positions other than the pre-head slot (Chaker 1983: 461; Lafkioui 1999, 2010, 2011a). The following are examples:

(7) Taqbaylit

y-Mut, amyar-Ni.

'He died, the old man in question.'

[Chaker 1983: 461]

(8) Tarifit

tokssi dəogya ddqar(,) tasriț-nnəs.

'She soon became pregnant, her daughter-in-law.'

In these cases, the post-predicative topic (right dislocation) is essentially marked by the intonation rupture that detaches it from the rest of the utterance (the comment). The FS marker corroborates this functional distribution; i.e. [COM = PS - IR $-\mathrm{T}$ ]. Right dislocated topics, such as in (7) and (8), usually serve as a discursive reminder, a means for ensuring the successful development and consolidation of the interaction. Moreover, topics also occur within the predication structure if they are backed up with appropriate intonation (often involving a pitch apex). This regular but less studied phenomenon in Berber linguistics indicates the pivotal role of prosody in the structuring of information. (For more discussion, see 2.3 and Lafkioui 2002, 2006, 2009, 2011a, 2011b: 93-128.)

\subsection{The prosodic parameter}

Of all identification parameters, it is intonation dislocation that constitutes the most distinctive feature of the marked topic in Berber (Lafkioui 2002, 2010, 2011a). In the case of the pre-predicative topic (left dislocation), the intonation pattern follows a pitch contour that reaches its peak on the ultimate syllable of the topic before it changes its direction on the first syllable of the ensuing segment, i.e. the comment. On the other hand, post-predicative topicalization (right 
dislocation) displays a prosodic configuration in which the pitch curve attains its maximum on the last syllable of the comment before descending on the first syllable of the topic. In both cases, it is intonation dislocation - ensured by an intonation break - that is the only conclusive defining element of the topic when it occurs in utterances without prosodic emphasis. As regards the pre-predicative topic, it is characterized by a pitch apex, as is confirmed in example (9) and its related Figure (1):

(9) Tarifit

tammūt-nni(,) din azğid.

'(At) that land in question, there (was) a king.'

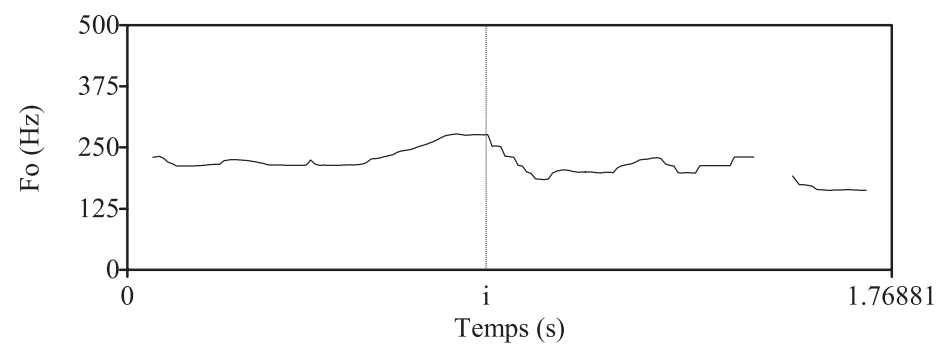

Fig. 1: Fo pattern for the occurrence tammūtenni(,) din azğid 'At that land in question, there (was) a king'

The instrumental analysis of (9) in Figure 1 demonstrates that the topic tammūt-nni ('land in question') is delimitated by a pitch apex of $276 \mathrm{~Hz}$ on its final syllable, immediately followed by a pitch fall starting on the initial syllable of the comment din azǧid ('there [was a] king').

\subsection{Topic co-referentiality}

In Berber, the topic has a predilection for reiterating its semantic referent in the comment by means of an anaphoric that assumes various actantial functions in the relating predicative structure. The only condition is that the co-referent has a notional connection with the predication in question, including the predicate itself, as is demonstrated in example (9) where the topic tammūt-nni ('land in question') is in co-reference with the adverbial predicate din ('there'). However, this rule does not systematically apply to circumstantial topics, among which much variation is observed. A language such as Tahaggart (Tuareg from the southern Algeria) allows for constructions without circumstantial co-reference 
(example 10), while a language such as Tarifit requires a pronominal co-referent

$(-s)$ in utterances like example (11):

(10) Tuareg

ahaGar, ak ayəraf itāGy ehwal əNìt

'(In) Ahaggar, each tribe has its brand (for livestock).'

[Foucauld \& Calassanti-Motylinski 1984: 125]

(11) Tarifit

taddart(,) wa day-s yudaf zi-mormi.

'The house, he did not enter it for ages.'

In addition, there is usually no matching co-referent when the topic refers to a generic notion. Undetermined topic referents, such as those illustrated in (12) and (13), block the co-referring procedure:

(12) Taqbaylit

ayrum, nečča.

'Bread, we ate.'

[Naït-Zerrad 2001: 160]

(13) Tarifit

bəțțu, noḅạa.

'Sharing, we shared.'

Constructions like (13) are recurrent in Berber and quite particular in that they have a fixed constituent order in which the fronted object-topic is a verbal noun derived from the same stem as the verb-predicate. These special marked topicalization constructions are usually employed for idiomatic purposes that engage a highlighting of certain semantic aspects conveyed by the relating verbal form.

\subsection{Topic superposition}

It is common practice in spontaneous Berber speech to superpose various topics in one and the same utterance, in narration as well as in conversation (Lafkioui 2002, 2010, 2011a). Natural non-elicited data point to their frequent occurrence (e.g. example 3), even in utterances like tigmmi-inu, $\boldsymbol{\varepsilon} \boldsymbol{m m i - k}$ i-zra-t ('My house, your uncle, he saw it.') from Mettouchi \& Fleisch (2010), which calls into question these authors' claim that this topic accumulation type is of exceptional incidence in Tashelhit. Moreover, based on evidence from Tarifit, Lafkioui (2002, 2010, 2011a) shows how superposed topics are prosodically punctuated according to 
the syntactic adequacy of the information structure in relation to the specific interactional context. Consider the following construction:

(14) Tarifit

baba zikl(,) ira $\dot{g} \bar{a}-\mathbf{s}$ sabera n tfunasin.

'My father, once, he had seven cows.'

Lafkioui (2010, 2011a) demonstrates that a pitch (Fo) progression of the topics $\underline{b} a \underline{b} a$ ('father') and zik ('once') at the same level marks not only that they are connected in terms of intonation but even in terms of information: both are introduced into the interlocution for the first time and, consequently, bring along relatively salient content; their information load is thus of the same importance. Furthermore, the privileged intonation-information structure of these topics is also consolidated by their close intensity (I) values. Lafkioui also gives evidence of how the identical morphemic configuration of (14) - which appears a second time in the same text but in a monologue section - connects with a different information structure through the modified prosodic features of the topics. In fact, the relatively lower value of the first topic and higher value of the second one points to intonation-information continuity.

\section{Cross-linguistic comparison}

This section presents a cross-linguistic analysis of the phenomenon of topicalization, with Berber as the basis for comparison. Special attention is given to the significance of topicality for topic selection, the co-referentiality phenomenon, the topic specification markers, verb phrase (VP) topicalization and the diachrony of topicalization with respect to constituent order.

\subsection{Topicality parameters and topic selection}

As is shown in section 2, Berber is consonant with the cross-linguistic tendency to prefer highly determined topics (Croft 1990: 112; Siewierska 1984: 221), especially when they are introduced into the utterance for the first time. However, less determined topics do also occur in many languages of the world (e.g. utterances 15 and 16), even if the required determination minimum varies from language to language. For instance, some African languages like Tupuri (15) and Berber (16) allow for the construction of topics on the basis of very weakly specified referents, which in English (17) or French (18) would be inadequate: 
(15) Tupuri

wäy pō, näarē $b \bar{\varepsilon}$ nàa.

'(There was) a chief, he has four wives.'

[Ruelland 2000]

(16) Tarifit

ižžən uzğid (,) ira $\dot{\mathrm{g}} \bar{a}$-s saḅca n yəssi-s.

'(There was) a king, he had seven daughters.'

(17) ${ }^{*} \boldsymbol{A}$ (certain) man, he had...

(18) *Un (certain) homme, il avait ... ('A (certain) man, he had ...')

It is worth mentioning that many Berber languages permit topics with very low semantic specification; e.g. the topic from (16) with the non-specification marker ižžən ('a' < ‘`one'), which refers to both an unspecified notion ('a king') and a feebly specified one ('a certain king'). ${ }^{5}$ In order to topicalize relatively unspecified semantic features, languages such as English (19), French (20), but also Hausa (21), require the insertion of existential markers (see text in capitals) that link the utterance with the discursive context and, in so doing, compensate for the lack of determination, as is exemplified in the following existential-presentative constructions:

(19) THERE WAS a man, he had...

(20) IL ETAIT un homme, il avait ... ('There was a man, he had ...')

(21) Hausa

àkwai WANI, kunàa tàarayyàn budurwaa, kai dà shii.

'There is a certain one, you court the (same) girl, you and him.'

[Caron 2000]

Furthermore, Berber languages are not the only ones to allow for unspecified topics conveying generic values (examples 12, 13 and 22). Indeed, this is a cross-linguistic phenomenon (Givón 2001: 265), which the following utterances from Hausa (23) and English (24) corroborate:

(22) Tarifit

asfạ̣(,) qa $\underline{d}$ asfađ̣.

'Dead wood, (it is just) dead wood.'

= 'The apple doesn't fall far from the tree.'

5 But there are also Berber languages that do not allow for such lowly specified topics, such as Zenaga (Mauritania, see Taine-Cheikh 2010). 
(23) Hausa

àbookin kuukaa baa àa booyèe masà mutuwàa.

'A friend of crying, one does not hide dead from him.'

= 'One does not hide the news of a death from the one who shares the grief with you.'

[Caron 2000]

(24) Democracy, what a joke!

The discursive referent of this kind of topic is prototypical and thus represents the whole semantic class in question. That is why generic topics regularly occur in expressive locutions such as these displayed here.

\subsection{Topic co-referentiality as a distinctive typological feature}

Topic co-referentiality is a widespread mechanism that often varies according to the referent's topicality traits. For example, as in Berber (see section 2), the Central African Banda Linda (25) and Tupuri (26) make general use of anaphoric co-referents when there is an actantial correlation:

(25) gūsū sáyē, ànjē mà àndà dà nà kó

'This straw, it is made into boxes.'

[Cloarec-Heiss 2000]

(26) hغ̀n 6̈̈, ndว̈ kò n gä búy

'Your sister in law, you don't know her at all.'

[Ruelland 2000]

On the other hand, West African languages such as Mòoré (Kaboré 2000), Dagara (Delplanque 2000), Fulfulde (Mohamadou 2000) and Hausa (Caron 2000; Newman 2000: 615-621) give more importance to the position of the nominal referent on the animacy hierarchy or to its degree of determination. For instance, in Fulfulde, the co-referent is mandatory when the topic referent is clearly determined (27) or when it connects with the subject-argument (28). Otherwise, there is no co-reference (29). This latter construction type mostly conveys generic notions, as is also the case in Berber (see examples 12, 13 and 22). Examples:

(27) Fulfulde

oya daada mum dabbit-i dum

'She in question, her mother went to search for her.' [Mohamadou 2000]

(28) Fulfulde

laamdo oo, o danyaay.

'This king, he did not have children.'

[Mohamadou 2000] 
(29) Fulfulde

guddol, be mbiidataa.

'Truncated (sentence), they do not say to each other.'

= 'They do not say a word to each other.'

[Caron 2000]

Moreover, in Central Africa, a language such as Gbaya marks co-referentiality for all arguments but the direct object:

(30) Gbaya

bêm kó tìtúù Pám zók bj̀ ná.

'Tituu's child, I do not see (him).'

[Roulon-Doko 2000]

Left dislocation without object-referent replication is also observed in English (example 31a), for instance, where it occurs in parallel with an alternative construction containing the anaphoric co-referent (example 31b); both options are equally valid.

(31a) This job, he will finish.

(31b) This job, he will finish it.

As for Berber, constructions like (30) and (31a) are not attested; co-referential resumption of the object-argument (example 32a of Tarifit) is required, as it is in numerous Indo-European languages such as standard French (example 33a):

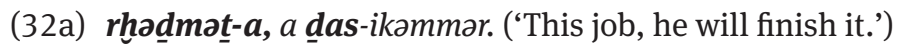

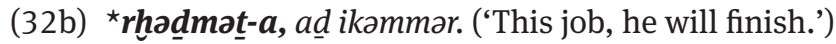

(33a) Ce boulot, il le finira. ('This job, he will finish it.')

(33b) ${ }^{\star}$ Ce boulot, il finira. ('This job, he will finish.')

\subsection{Topic specification markers}

In many languages, there are specific morphemes (mostly invariable particles) that mark the topic and so add particular semantic and discursive values to its referent by specifying its general content or by creating more contrast between its properties and that of the previous topic. Together with appropriate intonation, these markers also clearly set off the topic from its (mainly) succeeding comment. Some Indo-European examples of such commonly used markers which appear in a sentence-initial position are: the English as regards, as for, concerning, given; the French quant à, pour ce qui est de, concernant; the Italian per quanto riguarda, 
riguardo $a$; the Dutch wat betreft and aangaande. But postposed specification markers do also occur, in Berber (see example 36), for example, as well as in various West African languages such as Hausa (example 34), which distinguishes different particles that express divergent discursive notions, for example kùwa (contrast), $f a$ (discursive investment) and dai (discursive distance) (Caron 2000; Newman 2000: 616-617).

(34) Hausa

Kànde fa (...), mun fi sôntà

'As for Kande, we like her the most.'

[Newman 2000: 616]

Although specification markers are observed in Berber, they are not widespread. In fact, most accounts of regular usage come from Taqbaylit, where they precede the topic (e.g. ma d; example 35) and from Tuareg, where they are generally postposed (e.g. $z a$ in Tawellemmet and Tayert; example 36):

(35) ma d aqcic, tebbwi-t yid-es

'As for the boy, she took him with her.'

[Dallet 1982: 476]

(36) tagăyt-za, kannăn dăy-ăs ărătăn ăggôtnen

'As for the Doum palm, on the other hand, they make a lot of things out of it.'

[Prasse et al. 2003: 871]

It should be noted that topic specifiers are mostly optional in Berber and are primarily used for contrast-emphasis purposes.

\subsection{Topicalization of verb phrases}

Even if it is not always apparent whether languages directly topicalize genuine verb phrases or rather nominalize them first, one can classify them into two principal types - those languages with both nominal and verbal topicalization and those with principally or only nominal topicalization. Berber is essentially of the latter type, but in a less constraining way than languages such as French. Constructions such as (37), for example, are regularly attested in spoken Berber:

(37) Tarifit

ad səwwqวg்(,) inna-ay.

'I will go to the market, he said to me.' 
It is to be noted that the same mechanism for topicalizing NPs, and more precisely that for circumstantial and generic phrases, has been applied here for the VP ad səwwqวg ('I will go to the market'); that is, prosodically marked fronting without co-referential resumption. English too employs the same devices to topicalize both phrase types, even with arguments other than those conveying circumstantial or generic notions. Compare (31) with the following examples:

(38a) He will finish this job.

(38b) Finish this job, he will.

\subsection{Topicalization, constituent order and diachrony}

Even if Berber is commonly considered to have VS(O) as its general unmarked constituent order, it is subject to variation and, therefore, displays differences as to the relationship between the constituents' grammatical and discursive roles. Whereas pragmatics play an important role in the way in which core constituents are distributed in languages such as Tarifit (Lafkioui 1999, 2006, 2009, 2010) and Taqbaylit (e.g. Lafkioui 1999; Mettouchi 2005), in languages such as Tuareg Berber constituent order might be more grammatically motivated. But further study based on authentic and representative speech corpora are surely needed in order to acquire a better understanding of the syntax-pragmatics interplay in Berber. This would also help to verify the as-yet unsupported claim that, in certain Tuareg languages, the marked topic is undergoing the following grammaticalization stages (the last of which has not yet been achieved, though): [marked subject-topic > unmarked subject-topic > preposed NP subject]. ${ }^{6}$ In addition, it would allow the testing of various typological hypotheses about information structure in V-initial languages, and especially the idea that these lects tend to organize utterances in such ways that pragmatically marked information comes first (e.g. Payne 1995). Even if Berber (i.e. Tuareg) were to join the SVO grammaticalization tendency - although no empirical accounts support this possibility for the time being - it would be far from analogous to the diachronic transformations observed in strongly SVO languages with predominantly left-dislocated subject topics, such as French (Lambrecht \& Polinsky 1998). In fact, spoken French is currently transforming the left-dislocated subject-topic (Stage A) into a NP subject-argument which co-occurs with the co-referential pronoun and which

6 Galand (2010: 314) provokes this question en passant and very cautiously by saying 'C'est peut-être en touareg que l'évolution est le plus nettement amorcée'. 
contrasts with the new marked topic by intonation alone (Stage B). The next example meaning 'Sophie, she has eaten.' illustrates this:

(39) Sophie, elle a mangé. Vs. Sophie a mangé./Elle a mangé. (Stage A) Sophie, elle a mangé. Vs. Sophie elle a mangé.

(Stage B)

Whether constituent order is dictated by syntax or by pragmatics, fronting in Berber is clearly connected with discursive mechanisms, of which topicalization - the most examined one - is often combined with other functional devices such as emphasis or discursive investment marking. These mechanisms are produced in an incorporated manner in natural speech and are therefore difficult to distinguish when prosodic and extralinguistic features are not taken into account. These features are even indispensable when homomorphical units match different discursive functions, a recurrent phenomenon in Berber interaction (Lafkioui 2002, 2006, 2010, 2011a).

\section{Conclusion}

Berber is basically of the VSO type with a relatively flexible constituent order when it comes to identifying topic-comment functions and relations. Like other VSO languages (Creider \& Creider 1983), Berber tends to prepose the topicalized constituent in marked constructions and, accordingly, inverts the usual order for unmarked constructions; i.e. VSO (unmarked) > SVO (marked; S=T), thereby confirming Greenberg's (1963: 79) sixth universal, which states that VSO languages allow for SVO shifts. Pragmatic motivations (e.g. contrast-emphasis) are definitely behind the order inversion, which in Berber goes hand in hand with fronting mechanisms, the most crucial of which is intonation dislocation. This latter mechanism is also the principal feature of marked postposed (right dislocation) and intraposed (internally dislocated) topics, which occur frequently in spontaneous speech, mostly in complex constructions in which topicalization closely interacts with other discursive mechanisms. In such cases, prosody - in tandem with the interactional context - is one of the most important means for encoding and decoding accurately the information structure and its conveyed message. 


\section{Abbreviations}

$\begin{array}{llll}\text { COM } & \text { comment } & \text { PS } & \text { predicative syntagm } \\ \text { DS } & \text { dependent state } & \text { S } & \text { subject } \\ \text { FS } & \text { free state } & \text { T } & \text { topic } \\ \text { IR } & \text { intonation rupture } & \mathrm{V} & \text { verb } \\ \text { NP } & \text { noun phrase } & \text { VP } & \text { verb phrase } \\ \text { O } & \text { object } & & \end{array}$

Acknowledgments: This publication is made possible by a Fellowship grant from the Flemish Fund for Scientific Research (FWO).

\section{References}

Bentolila, Fernand (1981): Grammaire fonctionnelle d'un parler berbère. Aït Seghrouchen d'Oum Jeniba (Maroc). Paris: SELAF.

Brugnatelli, Vermondo (unpublished): Poesia religiosa tradizionale in Nordafrica. Appunti per la parte monografica del corso di Lingue e Letterature dell'Africa 2007-2008, Milano, Università degli Studi di Milano-Bicocca.

Caron, Bernard (2000): Assertion et préconstruit: topicalisation et focalisation dans les langues africaines, in: Caron, Bernard (ed.), Topicalisation et focalisation dans les langues africaines. Paris/Louvain: Peeters, 7-42.

Chaker, Salem (1983): Un parler berbère d'Algérie (Kabyle): Syntaxe. Aix-en-Provence: Université de Provence.

Cloarec-Heiss, France (2000): Focalisation et topicalisation en banda-linda, in: Caron, Bernard (ed.), Topicalisation et focalisation dans les langues africaines. Paris/Louvain: Peeters, 45-72.

Creider, Chet A. \& Creider, Jane T. (1983): Topic-comment relations in a verb-initial language, in: Journal of African Languages and Linguistics 5, 1-15.

Croft, William (1990): Typology and universals. Cambridge: Cambridge University Press.

Dallet, Jean-Marie (1982): Dictionnaire kabyle-français. Paris: SELAF.

Delplanque, Alain (2000): La place du contexte dans théorie de l'énoncé: topicalisation et focalisation en dagara, in: Caron, Bernard (ed.), Topicalisation et focalisation dans les langues africaines. Paris/Louvain: Peeters, 73-113.

Foucauld (de), Charles \& Calassanti-Motylinski, Adolphe (1984): Textes touaregs en prose. Avec traduction par Chaker, Salem; Claudot, Hélène \& Gast, Marceau. Aix-en-Provence: Edisud.

Galand, Lionel (1964): L'énoncé verbal en berbère. Étude de fonctions, in: Cahiers Ferdinand de Saussure 21, 33-59.

Galand, Lionel (2010): Regards sur le berbère. Milan: Centro Studi Camito-Semitici.

Givón, Talmy (1979): On understanding grammar. New York: Academic Press.

Givón, Talmy (2001): Syntax. Volume Il. Amsterdam/Philadelphia: Benjamins.

Greenberg, Joseph H. (1963): Some universals of grammar with particular reference to the order of meaningful elements, in: Greenberg, Joseph H. (ed.), Universals of human language.

Cambridge, Mass: MIT Press, 73-113. 
Kaboré, Raphaël (2000): Repère constitutif et marqueurs énonciatifs en moore, in: Caron, Bernard (ed.), Topicalisation et focalisation dans les langues africaines. Paris/Louvain: Peeters, 163-177.

Lafkioui, Mena (1999): Syntaxe intégrée de l'énoncé non-verbal berbère, PhD. Paris: INALCO.

Lafkioui, Mena (2002): L'intonation et ses fonctions syntaxiques en rifain, in: Naït-Zerrad, Kamal (ed.), Articles de linguistique berbère. Mémorial Werner Vycichl. Paris: L'Harmattan, 253-281.

Lafkioui, Mena (2006): Complémentarité syntactico-énonciative entre morphèmes et intonèmes. Le cas du berbère, in: Faits de Langues 27 (Volume spécial, Les Langues Chamito-Sémitiques II), 141-149 + références.

Lafkioui, Mena (2009): L'intonation et sa fonction de structurateur hiérarchique des syntagmes propositionnels sans indice morphématique. Le cas du tarifit, in: Chaker, Salem; Mettouchi, Amina \& Philippson, Gérard (eds.), Études de phonétique et linguistique berbères. Hommage à Naïma Louali (1961-2005). Paris/Louvain: Peeters, 109-121.

Lafkioui, Mena (2010): La topicalisation en berbère: formes et structures, in: Stroomer, Harry; Kossmann, Maarten; Ibriszimow, Dymitr \& Vossen, Rainer (eds.), Études Berbères $V$ - Essais sur des variations dialectales et autres articles. Köln: Rüdiger Köppe, 121-132.

Lafkioui, Mena (2011a): Intonation et topicalisation en berbère, in: Mettouchi, Amina (ed.), Mélanges offerts à Paulette Galand-Pernet \& Lionel Galand pour leur $90^{\circ}$ anniversaire. Köln: Rüdiger Köppe, 387-397.

Lafkioui, Mena (2011b): Études de la variation et de la structuration linguistiques et sociolinguistiques en berbère du Rif. Köln: Rüdiger Köppe.

Lambrecht, Knud \& Polinsky, Maria (1998): Typological variation in sentence-focus constructions, in: Singer, Kora \& al. (eds.), Proceedings of the Thirty-third Annual Meeting of the Chicago Linguistic Society. Papers from the Panels. Chicago, Illinois. 189-206.

Mettouchi, Amina (2005): Discourse-configurationality and the encoding of semantic macro-roles in Taqbaylit Berber: noun phrase, personal affixes and clitics, in: Mengozzi, Alessandro (ed.), Studi Afroasiatici. XI Incontro Italiano di linguistica camitosemitica. Milan: Franco Angeli, 83-96.

Mettouchi, Amina \& Fleisch, Axel (2010): Topic-focus articulation in Taqbaylit and Tashelhit Berber, in: Fiedler, Ines \& Schwarz, Anne (eds.), The expression of information structure: $a$ documentation of its diversity across Africa. Amsterdam/Philadelphia: Benjamins, 193-232.

Mohamadou, Alijou (2000): Topicalisation et détermination du terme topique en peul, in: Caron, Bernard (ed.), Topicalisation et focalisation dans les langues africaines. Paris/ Louvain: Peeters, 179-206.

Naït-Zerrad, Kamal (2001): Grammaire moderne du kabyle. Paris: Karthala.

Newman, Paul (2000): The Hausa language. An encyclopedic reference grammar. New Haven/ London: Yale University Press. Reprint of [1937].

Payne, Doris L. (1995): Verb initial languages and information order, in: Downing, Pamela A. \& Noonan, Michael (eds.), Word order in discourse. Amsterdam/Philadelphia: Benjamins, 449-485.

Prasse, Karl-G.; Ghoubeïd, Alojaly \& Mohamed, Ghabdouane (2003): Dictionnaire touaregfrançais $(M-Z \overline{)})$. Copenhagen: Museum Tusculanum Press.

Roulon-Doko, Paulette (2000): Hiérarchie dans l'énoncé gbaya (langue oubanguienne de Centrafrique), in: Caron, Bernard (ed.), Topicalisation et focalisation dans les langues africaines. Paris/Louvain: Peeters, 115-134. 
Ruelland, Suzanne (2000): Topicalisation et focalisation en tupuri, in: Caron, Bernard (ed.),

Topicalisation et focalisation dans les langues africaines. Paris/Louvain: Peeters, 135-162.

Siewierska, Anna (1984): The passive: a comparative linguistic analysis. London: Croom Helm.

Sudlow, David (2001): The Tamasheq of North-East Burkina Faso. Köln: Rüdiger Köppe.

Taine-Cheikh, Catherine (2010): The role of the Berber deictic and TAM markers in dependent clauses in Zenaga, in: Bril, Isabelle (ed.), Clause linking and clause hierarchy. Syntax and pragmatics. Amsterdam/Philadelphia: Benjamins, 355-398. 